1 「Gサイエンス学術会議」とは

Gサイエンス学術会議は、G7サミット参加各国の学術会議（科学アカデミー）による、G7サミッ トに向けた政策提言を目的として、2005年より発足した。同会議では、毎年、G7サミットの開催 に先立ち、世界の重要課題に関する科学的な政策提言のための共同声明を取りまとめ、G7サミッ 卜参加各国の政府首脳へ提出している。
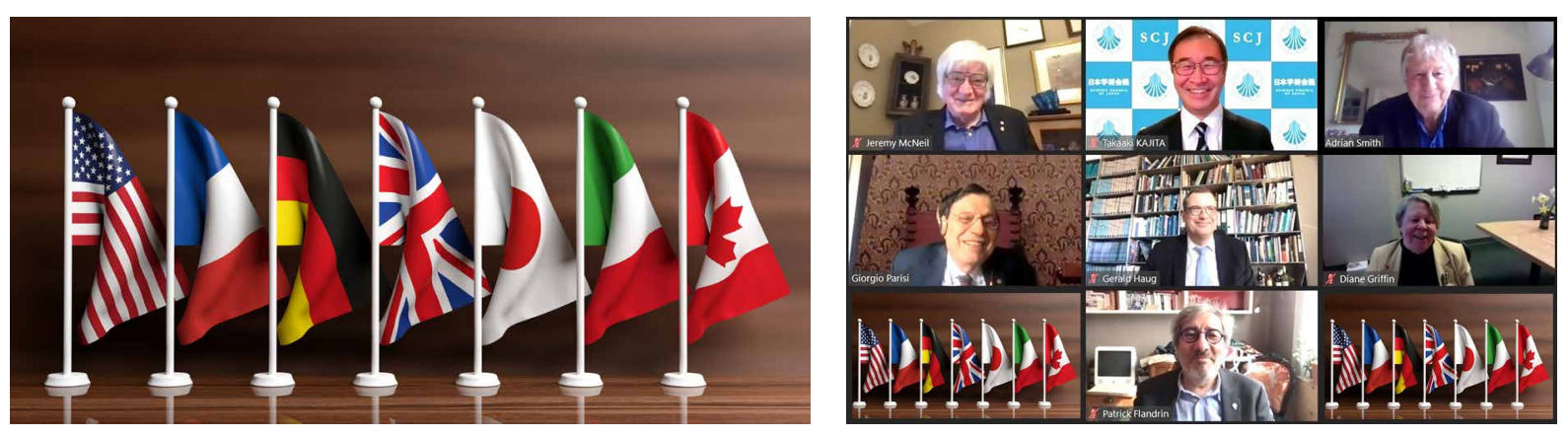

2021年の G7サミット議長国がイギリスであることから、本年のGサイエンス学術会議は、英 国王立協会（The Royal Society）の主催によりオンラインで3月 24 日に開催され、「ネットゼロと 気候変動影響に備えた未来一科学・技術と変化のための解決策 (A net zero climate-resilient future - science, technology and the solutions for change)」「生物多様性の損失を食い止めるために一早急 な対策の必要性（Reversing biodiversity loss - the case for urgent action)」「世界的な公衆衛生上の 緊急事態のためのデータ：ガバナンス、オペレーション、スキル (Data for international health emergencies: governance, operations and skills)」と題した3つの共同声明が取りまとめられた。

日本学術会議からは、事前に開催されたテーマ別専門家会議も含め、以下の6名が参画した。

- 梶田隆章：日本学術会議会長

・高村ゆかり：日本学術会議副会長（国際活動担当）

- 西山慶彦：日本学術会議会員 (京都大学経済研究所教授)

-亀山康子：日本学術会議連携会員 (国立研究開発法人国立環境研究所社会システム領域領域長)

- 橋本 禅 : 日本学術会議連携会員 (東京大学大学院農学生命科学研究科 (未来ビジョン研究 センター兼任) 准教授)

- 宇南山卓 : 日本学術会議連携会員 (京都大学経済研究所教授) 


\section{Gサイエンス学術会議（2021 年）共同声明の概要}

\section{ネットゼロと気候変動影響に備えた未来一科学・技術と変化のための解決策}

(A net zero climate-resilient future - science, technology and the solutions for change)

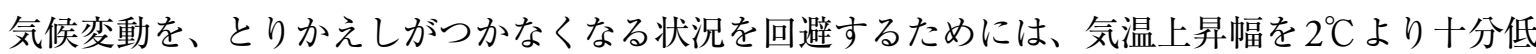
い水準、より望ましくは $1.5^{\circ} \mathrm{C}$ 以内に抑える必要があり、そのためには2050年までにネットゼロを 達成しなくてはならない。排出量大幅削減を実現するに当たっては、すでに実用化された技術の普 及を迅速に進めるとともに、未だ実用化に至っていない技術の早期開発及び実用化が急務である。 G7諸国は、これらの低炭素技術の開発及び普及により注力し、将来にわたって炭素排出を固定化 してしまう設備への投資を回避しなくてはならない。

十分にマネジメントされた緩和策や適応策は、持続可能な開発目標（SDGs）と整合する。食料・ 水の確保や貧困撲滅、エネルギーへのアクセスといった他の社会目標の達成も保証しつつ実施され ることが重要である。

ネットゼロ実現に向けたロードマップを提示する上で、科学技術は重要な役割を担う。科学は、 また、気候変動現象の進行状況を把握し、気候変動影響に対して適応していく上でも重要な役割を 果たす。このことから、Gサイエンス学術会議は以下を提言する。

1）ネットゼロに向けたエビデンスに基づく技術ロードマップを、科学者、経済学者、社会学者、 行動科学者からの意見を全般的に招集して、策定し、継続的に改定する。ロードマップでは、

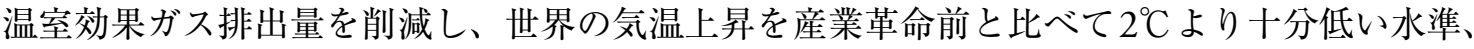
できれば $1.5^{\circ} \mathrm{C}$ 以内に抑制するために、展開・研究開発するべき技術を提言しなければならな い。

2）ネットゼロと効果的な適応に向けた課題に関する主要な研究開発への官民投資を増額するこ とにより、変化のスピードを加速させる。これは国単位、かつ、G7諸国の多国間協力にて実 践すべきである。

3）気候復元力の高い、ネットゼロの未来に向かうべく、中・低所得国を協力して支援する。

4）カーボンニュートラルな選択肢が経済的インセンティブとなるような、適切な政策パッケー ジに合意すべく、協力して取り組む。

\section{生物多様性の損失を食い止めるために一早急な対策の必要性}

\section{(Reversing biodiversity loss - the case for urgent action)}

今日、生物多様性の損失は人類史上これまでにない速度で進みつつあり、大量絶滅の危機に瀕し ているとの指摘がある。生物多様性の損失に関する明確な証拠の蓄積の進展や、保全に向けた野心 的な世界目標があるにもかかわらず、生物多様性の損失に対するこれまでの世界及び国家レべルで の対応は著しく不十分である。2020年9月に生物多様性条約事務局が発表した「地球規模生物多様 性概況第5版（GBO5）」では、「生物多様性条約戦略計画2011-2020」で定められた20の「愛知生 物多様性目標」がどれも十分に達成されていないことが報告されている。2030年までに生物多様性 の損失に歯止めをかけ、回復に転じさせるには、国や地域、国際レベルにおいて、技術的、政治的、 文化的、経済的、社会的な領域にわたる変革が必要である。自然のプロセスに国境がないように、 生物多様性の損失は世界的な問題であり、各国の連携が不可欠である。生物多様性条約第 15 回締約 国会議でのポスト2020生物多様性枠組が採択されることで得られる機会を無駄にしてはならない。 生物多様性の経済学に関する「ダスグプタ・レビュー」の発表や気候変動枠組条約第26回締約国会 議は、人間の福利を支える生物多様性の価值と重要性について、世界的なリーダーシップを発揮す る機会となる。G7諸国は重要なグループであり、自らが生物多様性の重大な損失を経験してきた だけでなく、現在も世界の生物多様性に依存し、また様々な商品の国際貿易を通じて世界各地の生 
物多様性に圧力をかけている。他方で、G7諸国は、研究ネットワーク、政治的影響力、資金力など、 変化をもたらすためのリソースも保有している。多国間の協調的な方法で生物多様性の損失に取り 組むことの緊急性と重要性を認識し、G7諸国は2030年までに生物多様性の損失を食い止め、回復 に転じさせるために協力すべきである。このことから、Gサイエンス学術会議は以下を提言する。

1）G7諸国は民間セクター、市民社会、先住民族、科学界など幅広い関係者と密接に協働し、以 下の点を踏まえた上で、生物多様性の価值を評価し会計処理するための新たな手法を開発す るべきである。

2）G7諸国は、統合的な地球システム思考を採用し、生物多様性、気候変動、その他の関連する 危機への分野横断的な対応策の考案を協調して行うべきである。

3）G7諸国は、各国の生物多様性目標の達成を促し、地域および世界規模の評価を推進し、保全 計画の策定を支援するために、世界規模の観測ネットワークに対して支援を行うべきである。

\section{世界的な公鼻衛生上の緊急事態のためのデータ : ガバナンス、オペレーション、スキル}

\section{(Data for international health emergencies: governance, operations and skills)}

新型コロナウイルス感染症によって人々の生命や健康が大きく損なわれ、これまで以上にデータ の重要性が高まっている。G7諸国はこの機会を捉えて、健康に関するデータを世界的な公共財と して確立するために、協力してデータガバナンスの原則とデータ運用の仕組みを構築し、同時に利 用者が適切にデー夕を取り扱うことが出来るスキルと能力を育成することが必要である。そして、 各国の新型コロナウイルス感染症への対応の経験から学び、公衆衛生上の緊急時に信頼できる国際 的なデータシステムの構築を支援するためにG7諸国の枠組みを超えた委員会を設立し、緊急時以 外においても世界の健康支援に資するような信頼に足るシステム構築を目指して各国が対話を重 ね、協力すべきである。G7諸国が協力することで、公䍃衛生上の緊急事態にデー夕を安全かつ迅 速に共有するための原則、システム、スキルの構築が実現し、世界的なパンデミックからの回復及 び今後の将来の世代の健康支援が可能となる。このことから、Gサイエンス学術会議は以下を提言 する。

1）公衆衛生上の緊急事態に対応するため、信頼性のある有用なデータへの安全なアクセスを可 能にし、その利用が促進されるよう、データ共有のガバナンスの原則を明確にし、仕組みを 設計することが必要である。プライバシーを保護しつつデータへのアクセスを可能にする技 術の開発を促進させるため、国際的な研究活動に資金を提供すべきである。

2）公衆衛生上の緊急事態のみに限らず、気候変動や生物多様性の損失などの重要課題においても、 各国で相互運用可能なデータインフラの構築に向けて専門機関のネットワークを設置するこ とが必要である。

3）データ管理、データ分析、データに基づく意思決定において個人のプライバシーが確保され 倫理的にデータを利用するにはすべての利用者がデータリテラシーを備えることが必要であ る。資金が十分に無い国へも各国のパンデミック対応におけるデータ利用の好例等を共有す るとともに、データリテラシーを備えた人材育成を目的として助成金や技術協力を含め、支 援すべきである。

4）上記の提言達成のために、有意義でオープンな対話を行う委員会の設置が必要である。この 委員会の当面の目的は新型コロナウイルス感染症への対応策で使用したデータを共有する手 順を定めることであるが、将来的に起こり得る様々な公衆衛生上の緊急事態へも対処可能と なるよう、常設とする可能性もある。G7諸国の枠組みを超えて、また公衆衛生上の緊急事態 以外においても、世界の人々の健康支援が可能となるためのシステムを構築し、来年以降の G7サミットにおいてもこの委員会の進渉状況を報告・共有し、引き続き検討を行うべきであ る。 